\title{
LXXI. Notes and observations on part of the eleventh and the twelfth chapters, and appendix, of Mr. Robert Bakewell's “Introduction to Geology;"-embracing incidentally, several new points of Geological investigation and Theory
}

\section{Mr. John Farey Sen.}

To cite this article: Mr. John Farey Sen. (1814) LXXI. Notes and observations on part of the eleventh and the twelfth chapters, and appendix, of Mr. Robert Bakewell's "Introduction to Geology;"-embracing incidentally, several new points of Geological investigation and Theory , Philosophical Magazine Series 1, 43:193, 325-341, DOI: 10.1080/14786441408638039

To link to this article: http://dx.doi.org/10.1080/14786441408638039

Published online: 27 Jul 2009.

Submit your article to this journal ¿

Џll Article views: 3

View related articles $\rightleftharpoons$ 
Liverpool, to be applied to the linch-pin of a carriage, to prevent the wheel coming off its axle, if the linch-pin should drop out; this contrivance being wholly applied at the extremity of the axletree, close to the linch-pin, it may be used in combination with Mr. Padbury's invention, and would then render a carriage so secure that it would be scarcely possible for the wheel to come off, by any accident short of the breaking of the axletree: and even then there would be a chance of the wheel being retained, in the circular box $\mathrm{EE}$, by the point of the screw $e$, so as to sustain the carriage from falling, until the horses could be stopped.

LXXI. Notes and Observations on Part of the Eleventh and the Twelfth Chapters, and Appendix, of Mr. RoEERT BakEWELL's "Introduction to Geology;"-embracing incidentally, several new Points of Gerlogical Investigation and Theory. By Mr. John Faney, Sen., Mineral Surveyor.

[Concluded from p. 261.]

$$
\text { Notes, } 8 \% \text {. }
$$

[P.274] 1. 8, of Craven in Yorkshire $\neq .-\$$ The north-western parts of which, at least, seem to have the same limestcne Rock as in North Wales, and in Shropshire, as Mr. B. is said to have represented, P. M. xxxix. p. 236, but not the same with the lowest of those in the Peak of Derbyshire, I think, see my lst Letter, vol.xlii. p.59, and 3d Letter, p. 170.

1. 12, exclude the coal **. - $*$ * The mode in which this exclusion happens, is very conveniently passed over in silence, see a Note in my 2 d Letter, vol. xlii. p. 105.

1. 18, a few miles only††.—†† Query, - see my lst Letter, vol. xlii. p. 57, and notes on p. 257 .

P. 275, 1. 14, Some traces of the rocks*.- * The great improbability of this supposed identity of the Peak Limestones, with those of Ticknall and Grace-Dieu, is heightened, by another supposition in p. 166, of Wild-Park, Breedon and Cloudshill, contorted magnesian Limestones (intermixed with these) being identical with the yellow Lime Rock, on the eastern side of Derbyshire, as observed in my Note on p. 167, see also my 2 d Letter, vol. xlii. p. 106.- "It will scarcely satisfy the curious to be tolk, that these lime rocks are mere anomalous masses," Mr. B. p. 46, in your xlth volume.

1. 26, west side of Anglesea +.- T The Coal-field in Anglesea is situated on its south-east side, rather, (see vol. xlii. p. 57) : here three seams of Coal of good caking quality have been wrought, at different times, in the parish of Llanfihangel Esceifiog, for ages past: the uppermost of these is X 3 
[P.275] a soft Coal, generally of five yards thick, the next a hard Coal, mostly of two yards thick, and the lower one is usually three quarters of a yard thick. Clunch or fire Clay occurs under each of these three Coals, as usual (Rep. i. 179 and 446 and P. M. xliii, p. 28), and Shale, Bind and Gritstone beds on and between them; altogether these Coal-measures seem about 150 yards thick : below the three-quarter seam, there is a thickness-perhaps 40 yards, of barren Coal-mëasures, in which, although the appearances are very promising and have induced several trials, seams of sufficient thickness to work, are rarely met with. Below this occur what I have denominated the Floor Rocks of the Anglesea Coal-trough, (vol. xlii. p. 356 and 360) and seem together to be about 90 yards thick, consisting of a variably and very coarse Gritstone with Jasper fragments in it occasionally; below which is a gray Limestone Rock (very cherty and bad in quality in Llanfihangel); then the middle coarse Gritstone Rock, often containing huge massesof Chert (as Graig-fawr, vol. xliii. p. 126) and Jasper fragments, coaly masses, \&:c. Below this the black Limestone or (Kilkenny) Marble Rock in thin beds, occurs; and thèn the lower variously coarse Grit Rock, graduating locally into Conglomerate, see my Note on p. 202 ; and then the coarse Slate succeeds. Both the Limestone Rocks ahove mentioned, are I believe included in the Halkin or highest of the three Limestone Rocks mentioned, vol. xlii. p. 53, 59, \&c.; in which case, they would with more propriety perhaps be called four Rocks of Limestone, that surround, and basset on more than three sides of the slaty mountains of Wales. And, if these are classed with the four Limestones of the Peak of Derbyshire, what very aromalous substances must we not admit, in the places of its three Toadstones?.

$277,1.8$, Hills in Derbyslire are *. - * Blakelow-stone is probably the highest; higher than Holme-moss, see my Notes on p. 272 and 278: Whin Hill and Mam Tor here mentioned, are inferior in height to several that surround them; Lords Seat near, at hand, over-looks them both.

278, 1. 21, has omitted the height*.-* Not exactly so, since the height of Axe-edge $\mathrm{N}$ hill is said to be 1875 feet, Rep. i. 17; at the time my volume was published, the List of altitudes in the "Account of the Trigonometrical Survey from 1800 to 1809 ," had not appeared: and even in this work, some difficulties arise, from Axe-edge and Lords-Seat, distant $49,212 \frac{1}{2}$ feet, (p. 128) and bearing about $31^{\circ} 42^{\prime}$ $13^{\prime \prime} \mathrm{E}$ of the $\mathrm{N}$, being each stated to be 1751 feet above the sea (p. 302 and 308); although, at Axe-edge, Lords- 
[P.278] Seatappeared depressed $3^{\prime} 53^{\prime \prime}$ (p.66), and atLords-Seat, Axe-edge appeared depressed $5^{\prime} 26^{\prime \prime}$; and some calculations will be necessary (which I have not now time for), to decide, which height is erroneous : that one of them, or of the depressions, must be so, is too apparent.

The other altitudes mentioned in this work, of Hills contained in my List, Rep. i. 16, and P. M. xxxvii. p. 161, are Alport (or Orpit) Hill of 1st Grit 980 feet, Bardon Hill of coarse Slate 8.53 feet, Bradfield Moor (or Point) of lst Grit 1246 feet, Hathersage Ridge of $2 \mathrm{~d}$. Grit 1377 feet, Holland (Hollin or Holin) Hill of Red Marl 487 feet, Holme Moss of 2d Grit 1859, Mole-copi of coarse Grit 1091 feet, Sutton (Sherwood) Forest-Hill of Gravel 600 feet, and Weaver Hill of 4th Lime 1154 fset.

1. 2-1, over Kinder Scout $\uparrow .-\uparrow$ This great and irregular Hummock of lst Grit (Rep. i. 226) has no particular summit, that is very decidedly higher than several others on its edges, much less, " 400 feet" higher, than any line which could be traced "over" this Mountain: Mr. B's Work would have suffered nothing, from the omission of the whole of this paragraph: and a piece of injustice to an Engineer of eminence, in publishing this statement would have been avoided: since I feannot doubt but Mr. Brown has been completely misunderstood by $\mathrm{Mr}$. $\mathrm{B}$. because, on reference to a "Plan of the Ashton under Line, Pesk Forest, Huddersfield and Rochdale Canals," prepared by Mr. Brown, for publication, by Mr.J. Cary, some years ago, whereon the levels are stated, of the existing Canals, it appears, that from the Duke of Bridgewater's Canal at Manchester to the Bugsworth branch of the Peak Forest Canal, the rises are 75 f. $7 \mathrm{in} .114 \mathrm{f}$. $6 \mathrm{in} .48 \mathrm{f}$. $0 \mathrm{in}$. and $212 \mathrm{f}$. $0 \mathrm{in}$; to which adding 82 feet for the Locks at Runeorn into the Tide-way in the Mersey, we have 532f. lin. for the elevation of Bugsworth Wharf above the Sea. It further appears from the Map referred to, and the ahstract of a Survey that was made under $M r$. Brown's direction in 1810, contained in Mr. Rennie's printed Letter of the 26th of October 1810, on the intended "High-PeakJunction Canal," that the further rises of $129 \mathrm{f}$. Oin. and $1 \mathrm{~s} 9 \mathrm{f}$. 9in. attain the summit level of this proposed Canal, which passing from near Malcalf through a proposed Tumel under Bouden-Edge, (which is between Lords-Seat and Kinder Scout) emerges again at Dale-end in Ecal Valley on the $S$ side of Kinder Scout mountain, and continues thence to skirt its southern flank to Nether Booth, before e lockage is to begin, for descending towards the eastern Rivers, (see Rep. vol. ii. chap. xvi. sect. 3 ).

Thi 


\section{Mr. Farey's Notes on Mr. Bakewell's Geology.}

[P.278] This summit level, at $809 f$. IOin. above the Sea, is probably much nore than " 400 feet" lower than the bold edges of the Kinder Scout Hummock, that over-look it, since this would make their elevation only 1210 feet, instead of $\mathrm{Mr}$. B's 2100 feet! or instead of 1770 or 1800 feet as ought I think to result, according to my comparative estimation, and recollection of the heights of these hills, and supposing that we can rely on the height of Lords Seat, as stated by Col. Mudge: and because Mr. Nuttall in 1789 found the summit of the Buxton and Manchester Road to be 1198 feet above the Cromford Canal, which probably is about 248 feet above the Sea, and gives this point of the Road an elevation of 1446 feet.

$279,1.15$, il rises to the surface*.--* Quere 1st or 4 th Limestone ?.- See my lst Letter, vol. xlii. p. 59, 2d Letter, p. 112, and $3 \mathrm{~d}$ Letter, p. 170 , and Note on p. 274, 1. 8 .

These Limestone Rocks Mr. B. represents as transition Rocks, (see Rep. j. 298 Note); yet a very principal of the Anglo-Wernerian Writers, after admitting that some petrifactions do occur in transition Limestone, lately said (Ann. of Phil. iii. 116 Note), "but hitherto as far as I know, no shells have been found in that Rock, nor anything else, except madrepores and othoceratites;"-let any one who has read William Martin's "Petrificata Derbiensia," say, whether this Wernerian dogma, will at all apply to the Peak hundreds of Derbychire? The Geognostic assertion, that particular Classes, Orders, or even Genera of organic remains, characterise the Formations, as to their relative ages, or priority of deposition, and the consequent order of the superposition of the strata, (see Ann. of Phil. i. 205): appears to me vastly inferior, either in truth or practical utility, to the discovery by Mr. Wrilliam Smith, about the year 1792, (Rep. i. 109), raade without communication with any Wernerian pupil (if any such had appeared in this country at that time?) as to particular species of Shells, \&c. that indiscriminately belong to different genera, orders, \&c. distinguishing, in a very marked and satisfactory manner, the greater part of the strata of England;-has Mr. Jameson told us in his account of "the Geognosy," the particular species of shells and other organic remains, or attempted it, that characterise the numerous strata of Scotland?, whence nearly all his British examples are drawn, or was he able to give such tests of his Geognostic deductions, as to any other country?.

281, 1. 1, red clay*.- * This Ironstone (like that near Coleford in Dean Forest and Merlin Griffith in Glamorganshire,) oc- 
[P.281] curs inVeins or Cavities in (probably the same, or Halkin?) Limestone Rock, P. M. xxxviii. p. 274, and Rep.i. 402 Note, and p. xlvii.

1. 9, the suljacent Rock +.- + Rep. i. 280.

1. 12 and 13 , rests upon slate.$+-\ldots$ This is an assumption supported by no just analogy, see my 1st Letrer, vol. xlii. p. 59, and Notes on pp. 274 and 279 .

1. I5, 250 yards**.- ***350 yards, and probably much more; the seven Rocks, four of Lime and three of Toudstone.

1. 17, varying much + t. - $+\uparrow$ Rep. i. 238 and 276 .

1. 20 , much thicker $\ddagger \ddagger .-\ddagger$ Rep. i. 280 .

$282,1.8$, our present manager*- - $*$ Mr. Theodore Silverwood, whose "Section" I have noticed, Rep. i. xxiv. but have therein, hardly done sufficient justice to his great kindness to me when on my Survey, or said all which I ought, of such a benefactor to the Science of Geology, in my $2 d$ Letter, vol. xlii. p. 109 ; and in the following page, I have omitted to mention, that the Section-line I have suggested, would, on the west side of Golden Valley, pass along the line of the Butterley Tunnel on the Cromford Canal, whereby an excellent Section that already exists, of 2978 yards in length of this line, in the possession of William Jessop, Esq. of Butterley Hall, would be brought into use, and rendered extremely interesting. When I was at Butterley, Mr. Jessop kindly lent me this Section to take with me to Mr. Muslet's, where it remained some time, and, if I mistake not, Mr. Silverwood made and retained a copy of it, which unfortunately I had not leisure to do myself, but was content with noticing an abstract of its results, the greater part of which will appear in my account of this Canal, in the 3d volume of my Report now printing.

$283,1.13$ and 14 , to reach the coal strata*.- Seven hundred yards is very far short of the probable distance, of even the Red Marl, (Rep. i. 116) below London, see my Note on page 259 .

1. 21, in Mr. Townsend's estimate + - + Which, of "the Derbyshire strata," has Mr. Townsend included in his account, quoted by Mr. B. p. 260 ?-Mr. T. says a great deal in his work, on very slender grounds, about the "Mountain Limestone" of Mendip and its neighbourhood, being the same as in the Peak of Derbyshire, yet he expressly says, it is a different stratum from the "Lyas," which last he states only at 20 yards thick, and the Mendip Rock is not therefore included in page 260. I think, that these Mendip strata are greatly thickened beds of the Lias, or perhaps of some of 
[P.283] its Marl beds, in a more perfectly calcareous and stony state, than usual, see my Note on p. 12.

$284,1.4$ and 5 , one mile and a quarter*._* Three Miles, P. M. xxxv. p. 130.

1. 8, I have before said †. - + See p. 262, and my Note thereon.

1. 10 , beyond the Peak $\downarrow .-\$$ Not on the surface ; because thrown down (comparatively speaking) by the great Limestone Fault, see my 2d Letter, vol.xlii.p. 112, and Note on p. 275 .

1. 12, appears to terminate***-- $*$ See my Note on p. 275 .

l. 17 , considered as primary $\uparrow+.-1+$ Although, $I$ never consider any Rocks in this light, for the reasons stated in P.M. vol. xxxix. p. 29, my Note on pp. 43 and 44, and elsewhere, yet I think I perceive (from pp. 57 and 85), that $\mathrm{Mr}$. B. here means "Transition."

1. 15 , extend about ten miles $+\ddagger .-\$ \ddagger$ See Map in Rep. p. 97 and p. 151 .

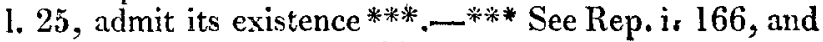
my 2rl Letter, vol. xlii. p. 108.

285, 1. 6, Basaltic rock near Nuneaton*.- See also p. 290. The Basalt at Griff-hollow, Marston, Harthill, \&c. occurs

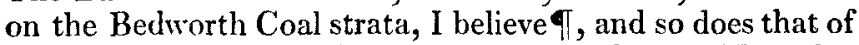
the Clee-Hills on its Coal-field (and the Rowley Hills also on another Coal-field, which circumstance Mr. B. has overlooked); and in assimilating these Basalts with the coarse Slate of Charnwood Forest (as I haye done, Rep. i. 155), both here and in page $290, \mathrm{Mr}$. B. was not aware probably, that he was indeed, granting my very heterodox position, as to the Ashby-de-la-Zouch Coal-measures passing-under

I Several months after this was written, my friend Mr. Benjamin Bevan (iv A pril 1814) informed me, that he had obtained Sections of the strata in the Bedworth Coal-field, and had certainly ascertained, that the regularly stratified Red Marl and imbedded Basalt or Greenstone, \&c. are laid unconformably over the dipping Coal-measures, in this case; in Somersetshire the sane was loug ago asserted by Mr. John Strachey, in No. 360 and No. 391 of the Philosophical Transactions; but after many conversations with Mr. Sinith and others, on the facts of the Somersetshire Coal-field, and very anxious inquiries, as to the correctness of Mr. Strachey's statements, I never conld obtain satistaction, as to the Red Marl, \&c. being regular and undisturbed, which had been proved by sinking through it, to overlie the Coal-measures in an ancontormable manner: and therefore I have always doubted the correctness of a fact, so very contrary to my own observations, and that of hundreds of others, in so many other situations, and so $I$ have expressed mysclf in my Notes on pages 45 and $98:-$ my zeal and industry shall however be increased, for inquiring fully into this important fact, and as to the extent of jts operation in the structure of England, and I shall be thankful for the assistance of your correspondents herein.

Charnwood 
[P.285] Charnwood Forest- " truth will now and then out;" see my Note on p. 67.

I long to examine the Malvern Hills, to see what I can make of them, and of the Coal-measures in their vicinity, of which my Friend Mr. Mushet speaks, P. M. xl. p. 54, and the Wrokin and Cardock Hills, \&c. p. 293, and the central parts of the South-Wales Coal-field, P. M. xl. p. 52.

1. 9, and Wales †. - † I am sorry that I cannot safely go thus far at present with Mr. B., unless he can show, that Basalt or its asociates, Porphyry, Sienite, \&c. see p. 97, and 289, (perhaps the "Pennard" Rock of Mr. Mushet, P. M. xl. p. 52?) are found on the central parts of Mr. Edw. Martin's great Coal-basin, (p. 268 and 299): not being able to admit, that the porphyritic green-stone on Cader Idris, p. 112,189 and 297, overlies any Coal strata, that I know of, in their vicinity. To me it seems not improbable, that the Coal strata of South and of North Wales, of Shropshire and Dean Forest and those of Anglesea, (see my Note orr p. 275) and even those of Antrim fo and Leitrim, Roscommon, Sligo $\uparrow \uparrow$ and Kilkenuy, were once spread, eren over Snowden, \&c. \&c. and were absolutely connected, before stupendous denudations separated them! see P.M. xxxvii. pp. 441 and 442.

1. 10 and 11 , nearly horizontal.$+-\neq$ Rep. i. 152 and 147 . 1. 11, sandstone**.- *** Red Marl with its gritstone and other imbedded substances, Rep, i. 154 .

1. 18, evidently formed from thempt. - + I maintain the Red Marl to be of the very same age with its various inbedded substances (even Granite, as Mr. Mushet mentions, P. M. xl. p. 53, and see Rep. i. 280), and so of any other stratum with respect to its imbedded masses, wiether Chalk and Flints, or micaceous Sandstone and Conglomerate, \&c. see my Note on pp. 43 and 44 .

1. 20, of fragments of these Rocks †.- $\$$ From this passage, any one would suppose, that fragments of Sienite and Slate were found in vast quantities, forming Breccia, or Conglomerate and Gravel, to the NW of Charnwood Forest; but no such thing occurs,'I think I can assure them, only occasionally, strata of variously coarse Gritstone, whose exposed surfaces are liable to be mistaken for Gravel Rocks, (Rep. i. p. xiii.); and on further search in Mr. B's Book,

T The information accessible to me in 1812 , seemed to leave it doubtful, whether the great Basalt of Antrim overlie its Conls, or not?, P.M. xxxix. p. 353, and sucb doubt still remains; but none I think, that there is a Basalt stratum on then.

भी Sir II. Davy in his i ric"iltural "Chenistry" informs us, that many of the highest hills in these Coal-felds " have basaltic summits." 
[P.285] these multitudes "of fragments" are supposed to be derived from supposed veins of white Quartz, (p.287 and 188) and by suppositions, equally probable, these fragments of quartz, in travelling a Mile, or 20 at most, within the distance here alluded to, are supposed to be in a great degree if not perfectly rounded!!, see my Note on page 188 .

286, I. 4, of sandstone*.- * Red Marl, see ny Note on p. 67 . 1. 7 , rests on the flankst.- + When $I$ examined this Forest, it was in too much haste, as observed in my $2 d$ Letter, vol. xlii. p. 116; had it been situated in Derbyshive, it would have had a far more minte examination, and I should have been able to speak rather positively, as to what thick Rocks would be seen in ascending any particular Brook (except perhaps in some Coal-districts, here I cannot he equally confideut. In page 158 , vol. $i$. of my Report, I have mentioned the appearances, as justifying the inferenoe, that the Grace-Dien limestone rock passes under tho Forest Slate: and when I now recollect, the confidence with which Mr. B., from Theory only, has asserted, in his Note on page 266 (see my Note thereon), that similar discoveries of louer strata might be made, by ascending the ravines in the North Eastern Moorlands of Yorkshire, he must excuse me for continuing to think, that he is not less mistaken as to the Grace-Dieu ravine, until I shall happen to have the opportunity of examining the spot more minutely, or of learning the observations of others, who have so exanined it.

1. 15 , its termination at this place $\downarrow .-\downarrow$ See my Note on p. 275 .

1. 16, singularly contorted **. - ** Rep. i. 159 .

1. 20 , nodules of lead ore $+\uparrow .-+\uparrow$ Such bolders are found oceasionally, where no adjaccnt Limestone Rock and Lead Veins, can easily be supposed to have disappeared, as in the Gravel Pit at Wyastón, Rep. i. 372, \&c.

287, 1. 5, at Barrow on Soar*.—* Blue Lias T, Rep. i. 115. How Mr. B. makes this place to be "on the other side of

9 This remarkable Limestone Rock (see top of Mr. B's page 16), from its prolanic property, the fossil Bones and Aat scaly Fish, the Pentacrinus, \&c. \&c. that it contains, seems to me, from the translation of M. Cuvier's Creology, y. 260, to enter the Coast of France at the mouth of the Seine, and to pass inland by a circuitous route westward, to Alençon in the departwent of Orue, and perhaps in the dep. of the Mayne and Loire, \&c. If I am right in these conjectures, the fine Bath Oalite near Caen in the department of Catvados, whence it is said that Heury the Seventh's Chapel in Westminster was built, probably occupies the tops of the hills (unless a depression or trough occurs there?) as it does to the $\mathrm{E}$ and SE of Bath, (see my $2 \mathrm{~d}$ Note on page 167); the Bridge in which last City, stands on the eastern edge of the ring of Lits, that surrounds another of Red Marl, including and overlicing a Small denudated Coal-field, occurring between Bath and Keynsham.

the 
[P.287] the forest" from the Canal or Water-level belonging to the Leicester Navigation (in the cutting of which, nodules of Lead Ore were found, as mentioned in his Note on the precering page) I am at a loss to conjecture; when they are more properly on the same side, and the general direction of this crooked Canal points for Barrow on Soar. Without doubt, I think, the Lias strata, on Red Marl, once overlaid the whole of Charnwood Forest (but not any of the Limestones of Derbyshire) before the Denudation thereof, (P. M. xxxvii. p. 442); and it is perhaps equally probable, that the bolders of Lead Ore mentioned, may be moved from the edges of the Lias strata, or some others further eastward, and lodged in the Gravel on the Forest, as that they are the produce of thin and perhaps unconnected veins of Lead Ore, in the coarse Slate, of the spots where they are found. Spars of any kind, are rarely found, in many of the Lead Mines in Cardiganshire, owing to which, the discovery and tracing of Veins there, is far more difficult than in the Peaks of Derbyshire.

1. 18, the slate quarries.+-+ Rep. i. 153.

288, I. 3, erroneously stated*._. Rep. i. 19.

1. 5, the beds are more regular t. - + In sudden Ridges, with various apparent dips, at Swithland, \&c. Rep. i. 154 .

1. 15, nearly at right angles*. - Said to be $60^{\circ}$ at page 87 , and in " an opposite direction," P. M. xl. p. 47, see my $2 \mathrm{~d}$ Letter, vol. xlii. p. 116.

$289,1.11$ and 12 , these rocks are cotemporaneous*.i. 153, Phil. Trans. 1811, and P. M. xxxix. p. 28, see also my Notes on pages 43 and 285.

$290,1.18$, inclined as if it rose*.cover, Rep. i. 153, and p. 155 Note. 19.

1. 20 , and Beacon Hill is flinty slate.$+-\uparrow$ Rep. i. 18 and

1. 23 and 24, gridations from sienite.$+-\ddagger$ Rep. i. 153 and 154 .

291, 1. 3, whetstone or hone*.- -* On Whittle Hill, Rep. i. 61 and 439 , see my Note on p. 171.

l. 4, Markfield Knowl†.—† Markfield Windmill-hill, Rep. i. 45 and 144.

292 , I. 1, deep perpendicular fissures*.-* Occasioned by the shrinking of the thick beds or masses, in unequal degrees, as is often to be observed in Cliffs and Quarries.

1. 16, concealed by plantations and inclosures + . - t The many openings and excavations which will be made in the surface, by the formation of the Roads, and digging of 
[P.292] Stone for them, and the Walls, searching for Slate, (Rep.i. p. 154 , at bottom), \&c. \&c. will greatly increase, instead of diministing, the means of observation and of understanding the internal structure of this curious district.

293, 1. 17 and 18, covered with Limestone*. - * On their western side only?, P. M. xl. p. 54.

$294,1.18$, natural history of the island * _ * In August 1807, the materials were begun to be collected, on a comprehensive plan, for a Mineral Map and History of Derbyshire and its Environs, and the ciell work thereof was persevered in, until November 1809: an alstract of all the most generally useful parts of which, were purchased by the Board of Agriculture (Derby Rep.i. p. v. and vi.), and 150l. paid to me for the same, on the 29 th of April 1810 . In the following: Month, Mr. Arthur Aikin 9 issued a Prospectus of the Shropshire Survey here alluded to by Mr. B., the field business of which is yet in hand, I believe.

On the 12 th of June I waited on the Board, by desire, and, as I had before done, produced and explained my large and reduced Mineral Maps, Sections, \&c. T $\uparrow$ and a part of the MS. of the lst vol. of my Derby Report, (since published by the Board in June 1811); soon after I retired, the Session of the Board for the year 1810 was closed, by a long Speech from the President Sir John Sinclair, which was soon after printed and circulated. In this Speech, a general review was, as usual, taken, of the proceedings of the Board, as to the commencement, progress or conclusion, of any part of the labours intrusted to them by the Government and the Country; and herein it was stated, that the Board had recently patronized the Survey of Shropshive by Mr. Aikin, concluding thus, "and which is the first attempt of the sort, on a regular and extensive plan ;" and yet, not a mention or

T One of the Council and Secretaries of the Geological Society, see a Note in my 1st Letter, vol, xlii. p. 56.

II Mr. William Smith has in like manner, on different occasions, attended meetings of the Board of Agriculture, and submitted and explained his Mineral Maps and Sections, of great part of England, as I have mentioned or hinted, P. M. vol. xxxix. p. 426 , and xxxv. p. 114. In Mr. S. and my own cascs, the matters thus submitted, in hopes of obtaining the efficient patronage, for kack of which, they are yet unavailable by the Public, (P. M. xlii. p. 109, and 246) were not merely, proposals and promises of fieldbusiness, intended to be undertaken, and of Maps, \&c. to be prepared therefrom: but the large Maps, Sections, \&c. themselves, which had been the results of unwearied researches for years, and of expenses to the parties, almost beyond their private means. - Mr. A's patronage, and Geognostic connections, witl, is is hoped, produce to him a very different and more agrecable result, 
[P.294]most distant allusion was made, to my Derlyshire Mineral Survey, or, as to the Board having contracted for the Manuscript of the first Mineral Report on the English Counties (which series had been promised ever since 1793, Rep. i. pref. vi. and P. M. xxxrii. p. 8) in this Speech, or in any other announcement from the Officers of the Board to its Members or to the Public, as far as I have heard :-I forbear further comments.

295, 1. 22, similar to the limestone*.- ** And supposed to be the same, in pages 220 and 274 , see my Note on the latter page.

1. 24, eastern side of North Wales $\uparrow-\longrightarrow+$ It is not on the eastern side only, of the northern Cambrian Mountains, that Limestone Rocks underlay Coal-measures, but on the NE and NW sides also; the latter calcareous Rocks, stretching across Anglesea, see my Note on page 275 .

296, 1. 18, said to occur in Anglesea *.- * During my stay in this Island, I saw, or could hear accounts from the inhabitants of no Rocks of Granite : the Mile-stones on the Post Road, seemed formed of reddish Granite, and occasional loose blocks of it were met with on the surface : but Mr. Wilson Lowry has since informed me, that in travelling across from the Post Road at Gwndy to the Paris Mountain, he saw low Rocks of Granite, not far from the former place.

1. 22, from its hardness, beauty †. $\rightarrow+$ See my Note on p. 92. Very considerable Rocks of Serpentine are found in the coarse Slate of the NW and W parts of Anglesea.

297, 1. 9 and 10, sulphurous limestone*.- ${ }^{*}$. See my Note on p. 98 .

299 , 1. 20, boundary of the coal strata*.- $*$ See p. 268. A similar "6 concavity" or trough of the same Limestone, seems to underlie the estuary of the Dee, and the Coal-measures therein, seem to extend from Flint to Park-Gate: how far this Coal-basin extends westward, under the Sea, towards the north Coast of Anglesea, \&c. we have yet in part to learn, see my Notes on p. 108, 275, and 285.

300, 1. 10, part of Somersetshire *._* But a very small part of this County, the Quantook Hills, at its western extremity, can I think be either "primary" or "transition ;" unless that Lias, Red Marl, and Coal-measures under these, are so? see my Note on pages 12 and 283. Mr. Thomas Allan says in the Edin. Trans., that in his way to Exeter, he first saw " transition strata between Bridgewater and Taunton :" but on reference to the Appendix to his paper, No. 1 and 2, it appears, I think, that the imbedded Grit-stone in the 


\section{$336 \mathrm{Mr}$. Farey's Notes on Mr. Bakewell's Geology.}

[P.300]Red Marl, something harder than usual perhaps, and tilted, has been so denuminated; for, near to 'Taunton, on the SE, the Lias occurs again, as 1 have been informed.

302, 1. 11, and worn down *.. * See Mr. John Hutchinson's Works xii. p. 261 and 338.

$303,1.3$ and 4 , as a field bean*._. Some of the pieces of Gold from the Wicklow Mountains are much larger, appearing as if kneaded into their present form, by violent pressure (if not aggregated by this means), and containing some fragments of yuartz, which appear forced into the gold.

304, 1. 2, and warm springs *._* Should not cold or ordinary Springs also have been noticed in Mr. B's worh?, and their undoubted sources from the inflitration of rain waters been particularly mentioned: few of the Geological phænomena are of more general interest, or have been more superficially, or erroneonsly treated by Writers; see Rep, i. 500.

1. 10 , under the whole district $f .-\uparrow$ This is unsupported by any facts or observations in the Mines, \&c. Rep. i. 487.

1. 16 and 17, the Crom ford Canal + . - The cause of the temperature of the western end of this Canal being often higher than usual, is perfectly apparent: it is fed by the large stream of very urarm water issuing from Cromford Sough, (Rep. i. 329, and vol. iii. chap. xvi. sect. 3), on Sundavs and often in the night, when Mr. Arkwright's Cotton Mill is not at work.

1. 19, be frequently seen rising . - *** Since Mr. B. told me in May 1812, of this supposed prevalence of urarm springs and general heat in the strata, through which the Cromford Canal is cut, from Cromford to near Crich, I have made very particular inquiries, while in the neighbourhood, and concerning the Person, formerly of Crich, whom he mentioned as his informant. The hot spring which rose at MiddletomWood Bath, (Rep. i. 505), in Bonsal Dale, close by the side of the great Limestone Fault, (Rep. i. bottom of p. 281 and in p. 282), until that by the driving of the Cromford Sough, a porous stratum of Limestone, or a line of fissures thercin, connected with it, let off its hot water; at a much lower level, and mixed it with a great deal of cold water, which the songh still collects, on both sides of that which enters it hot; this mixed water, almost daily let into the Canal at its upper end, will perfectly account for all the volcanic wonders, which are here accumulated by Mr. B.; see my Note on p. 226.

$305,1.1$, principally confined to Basaltic ${ }^{*} .{ }^{*}$ Where are the Basaltic 
[P.305] Basaltic strata, or the volcanic substances, near to Bath andBristol ?: whose Springs seem to me to rise, from some certain stratum in or near the Lias Limestone; as a line of Mineral Springs also do, at Cheltenham, (and several places in its neighbourhood, P.M. xxxii. p. 59), Lemington-Priors, Kings Newnham (Warwick. Rep. p. 28), and other places, across the greater part of England.

1. 10 , situation of the warm springs $\uparrow .-1+$ These in Derbyshire, rise by the sides of the great Faults, see Rep. i. 503, 504,505 , and my Notes on p. 226 and 304 .

$306,1.20$, that clearly indicate ${ }^{*}$. ${ }^{*}$ Hot springs, and strongly mineralized ones, more clearly indicate the existence of Fanlts, and the chemical and perhaps the Voltaic action of strata on each other, than point out dormant Volcanoes, see my Notes "on p. 226 and 304.

$309,1.20$, never will be accomplished*. - ${ }^{*}$ Why not ?-If Mr. B. could have found as many materials prepared to his hands, respecting several other English Counties, as he lias with respect to one, he might have given us a work, far more distinguished by variety, and truth of representation.

1. 25, is what ignorance and cliance t. - + Did these alone, produce the "Mineralogia Cornubiensis" of W. Pryce, "British Mineralogy," by J. Sowerby, "The Mineralogy of Derbyshire," by J. Mawe, \&c. \&c.? or did they (ignorance and chance) set on foot, the Surveys of Dumfriesshire, Shropshire and Derbyshire? To sizy nothing of Mr. Smith.an Advertisement, such assertions as these may pass current, but ought to have heen more cautiously introduced into an elementary work on the science.

$310,1.10$ and 11 , the $y e$ er $1804^{*}$ - * $^{*}$ This circumstance, so perpetually referred to by Mr. B. in his writings, happens to be rather incerrec, see my Note on $\mu .221$.

$311,1.24$, resmblarige to the Welsh limestone $*$ - The pozolanic quality of the L'tue Lias, near Bath in particular, (where the name origiated) has ben well kno'sn for ages, and particularly so since 1791, when Mr. Smeaton made it so extasively knowi, by his publication on the Eddystone Light-House, and since 1794 or 5 , when Mr. Sinith began to exhibit at Mitford and Bath, \&c. his Maps showing the range across England of this very important stratum, see Rep. i. 114, and P. M. xxxvi. p. 105: its use in Coalmines, I have mentioned, Rep. i. 327 .

$314,1.1$ and 2 , its affects on a large scale ${ }^{*}$. - Rep. i. 153. Phil. Trans. 1811, and P.M. xxxvii. p. 441, and xxxix. p. 29 and 426.

Vol. 43. No.193. May 1814. Y Y 1.24, 
[P.314] 1.24, if slowly cooled †.- + At the Iron Furnace (and Coal-works) to which Mr. B. alludes in p. 282, Mr. David Mushet observed, that the Slag let ont of the Furnace and quickly cooled by throwing water on it, had often, perfect short octagonal prisms of whitish slag, found in cavities within it, and some snall transparent cubic crystals, \&c.

$315,1.7$, shrinking in of the basalt* —* The crystallization of Basalt on the large scale, is so imperfect, before exposure on or near to the surface, that it is found a solid and homogeneous Rock (except as to imbedded masses), whenever sunk or driven to, in the deep, in Mines, and the amygdaloidal holes are then all full of spar, \&c. Rep. i. 277, see my Note on p. 123, and P. M. xliii. p. 136.

$317,1.4$, is owing to the mica*.- - Rep. i. 428 and 466 .

1. 9 , dividing in a contrary direction $\uparrow .-\uparrow A$ phrenomenon regarding stratification, which I have called stratula, Rep. i. 155, is here alluded to, and it rather surprises me, that Mr. B. has not in his work, taken more notice of the fact, that in many Coal-measure and other Rocks, of Gritstone in particular, certain beds, are uniformly crossed at a high angle by inferior stratification; these stratula ending with an oblique or bevelled end at top and bottom: in different beds in the same quarry, the stratula will sometimes be found inclined at different angles, and sometimes in contrary directions, from those in other Beds. Writers seem to have been little acquainted with this phænomenon, (Mont. Mag. xxxiii. p. 517, P. M. xxxviii. p. 357, \&c.) and many erroneous descriptions of the dips of strata have been given in consequence. Mr. Townsend supposed, when he saw the stratula of a thick bed of Rock near Bath, that an enormous convulsion had happened, by which the strata were first tilted almost to an angle of $46^{\circ}$, and then their top edges (and he tells us nothing of their bottom edges) were swept or worn off to an exact plane, and that after this, other strata were horizontally deposited upon them! Such, I am inclined to think, have in niany instances been, the " unconformable" masses, described by the Anglo-Wernerians, see my Note on p. 45.

$318,1.9$, was in a solid state*.- ${ }^{*}$ As happens very frequently to Gritstones, with argillaceous cements, which are burnt for the Roads, (Rep. i. 164, and iii. 256), and thereby assume a pretty regular columnar structure.

$325,1.22$, great ecliptic days*..* But why need these grand events be measured by days of any kind ?. The Mosaic account, here obliquely glanced at, does not require it; if all 
[P.325] the stratified Animals and Vegetables, successively existed and became extinct, as the strata were successively Created, before the periods called days (but improperly so in our translation) commenced, and to which Creation of matter and of the now extinct organized races, only the very first words of Moses apply, see the articles Coal and Colliery in Dr. Rees's Cyclopædia.

$327,1.6$, in the upper strata*.- * In alluvium upon the strata, see my Notes on pages I6 and $18 \mathrm{I}$.

328,1 . 15, astronomy for the discovery *.- * Perhaps a more extended and minute application of Gravity and tidal action, than has yet been made, will solve many difficulties, as to the changes that the Earth has undergone, P. M. xxviii p. 128 and xxxix. p. 358 note, and my Note on p. 192.

$329,1.8$, concretion of stony masses *.- * Is it not far more probable, that the meteoric stones have existed through many ages as satellitulce of our Planet, and visit our Atmosphere at very short intervals, when in Perigeo, as Shooting Stars, see Mr. Nicholson's Journal, vol. xxxiv. p. 298: the hypothesis that makes each one of them a separate volcanic Bomb from the Moon, seems a very lame and unphilosophical one.

335, I. 4 and 5 , succession of different soils*.—* See P. M. xxxv. p. 116.

l. 6, extraordinary organic remains $\uparrow .-\uparrow$. M. $x x x v$. p. 124.

1. 28, of fresh-water shells $¥ .-\ldots$ Query ?-see my Note on page 160 . Mr. William Smith lately informed me, that in driving piles for a drainage Sluice on the sea shore at Minsmer $\mathbf{S}$ of Dunwich in Suffolk, the bottoms of them, below the Sand, entered a soft limestone Rock, which he stated, may very probably be part of the same stratum as that at West Cowes on the northern coast of the Isle of Wight, that has been supposed to contain the fresh-water shells, to which $\mathrm{Mr}$. B. here alludes.

$336,1.6$, in the following order*.- * See P.M. xxxv. p. 140.

1. 13 and 14, and Gypsum +. - + See my Note on page 173.-The Paris Gypsum, \&c. seems to have been traced through France, to the confines of Switzerland; and isolated hummocks of it to appear, far north-east of the Paris Basin, (as it is called) at Luneberg in Hanover, and at Segeberg and Kiel in Holstein, according to Dr. Steffens and M. De Luc. At Luneberg and at Oldersboke near Segeberg, strong Salt Springs arise, from this Gypsum stratum, I believe. 
[P.336] 1.24, black earth †.- $\ddagger$ Bones of Elephants, Oxen, Antelopes, \&c. and large Trees, \&c. are found in this most recent allivium, with rounded Flints, \&c. P.M. xxxv. p. 58 , see my Note on page 181.

P. 343, 1. 1!, composed chiefly of gravel*.-* Rep. i. 252. $344,1.28$, with a floor ${ }^{*}$ - $^{*}$ A rib or skirt, of Cawk, \&c. 350,1 . 15, indurated clay ${ }^{*}$ - ${ }^{*}$ Bind is indurated Loam, and Clunch is indurated Clay, see p. 351 , and Rep. i. 445 and 446.

1. 23, composed of rounded stonest.- + Breccias contain angular stones or rubble; Pudding-stones contain round nodules; and Gravel Rock contains rounded stones. Rep. i. 142.

$351,1.8$, sulphate of barytes ${ }^{*}$ - $*$ Sce Rep. i, $355 \mathrm{~N}$.

$3.52,1$. 15, Dip, the point of the compass*.- * The most common and proper application of this term, when used alone, is to the degree of descent or inclination, which practical Men express in numbers thus, 1 in 5, and authors for the same write, $11^{\circ} 32^{\prime}, 8 c$. The point of the compass or direction of the dip is necessary also, as SE or $\mathbf{E}$ $45^{\circ} \mathrm{S}$.

$361,1.22$ and 23 , upon the above plan is new*. - ${ }^{*} \mathrm{Mr}$. Wm. Smith, Mr. John Farey, Sen. Mr.'Thomas Bartley, (formerly a Clerk and Assistant to Mr. Smith), \&c. did the same, for various Noblemen and Gentlemen, long before Mr. B.

Poslscript.-I beg to mention, before I close these Notes, that it appears by a Letter of the 29th of April 1814, from Mr. Elias Hall, of Castieton, to Sir Joseph Banks, Bart., which he did me the honour to show me, that in the present Spring Mr. Hall has extended his survey northward from the Peak of Derbyshire, and made a Model, (see P. M. xlii. p. 113) of the Strata of the Grand Ridge, and the adjacent country east and west of it, almost as far as Westmorland; and that he finds Pennigant Hill, $\mathrm{N}$ of Settle in Yorkshire, to be capped with the 2d Grit Rock, and to have a basis of 1 st Limestone.

More than ten years ago, I learned from Mr. Wm. Smith, that Whernside hill, about $6 \frac{\Gamma}{2}$ miles NW of Pemuigant, was capped with Coal-measures (although esteemed there, to be the highest hill in England); and this latter circumstance it was, as well as the want of evidence offered by Mr. B., either in his Lectures or his Geological Work, of his favourite position; viz. that the 4th Limestone shewed itself in the lower parts of these and Ingleborough Hills, and Slate from under this lowest of the Derly, hire Peak Limestones, which inade me doubt the cor- 
rectness of Mr. B's observations, and occasioned me to resist his conclusions, as I have done in my three Letters and Notes on Mr. B's Work, in this and the previons volume of the Phil. Mag.

Mr. Hall's observations seem to me to render it now almost certain, that Mr. B. has mistaken the 1st Limestone Rock for the $4 \mathrm{th}$, as I have often before hinted, and the result secms an important one; viz. that the Slate of Ingleborough (see vol. xlii. p. 59 and 170) must probably be referred to the same stratum as the Ist Toadstone of Derbyshire! instead of a stratum under the 4th Limestone, as Mr. B. has contended. How far this new suggestion, of which I have recently added a hint, in my Note on page 275 , may be correct, and its infuence may extend towards the explanation of the real structure of the British Isles, I shall be industrious to inquire, and shall gladly receive the facts or suggestions that your Correspondents may be able to offer : the means for which will now I trust be greatly extended, by the speedy publication of $M r$. Smith's large in ap of the Strata, which may now be seen, in part, and Prospectus obtained, by application to Mr. John Cary, No. 181, Strand.

I am, sir, your obedient servant,

12, Upper Crown Street, Westminiter.

John Farky, Sen.

To Messrs. Nicholson and Tilloch.

LXXII. Facts and Olservatinns towards a History of the Combinations of the yellow Oride of Lead with the Nitric and Nitrous Acids. By M. Chevreul.

[Continued from p. 270]

Analysis of the Nitrites of Lead.

30. $T_{\text {He nitrite of lead, when exposed to the sun for several }}$ dars, retains some water, as we may see on heating it in a long close glass tube: that which has been exposed in a retort at the heat of boiling water, until no more humidity is extricated, loses a portion of acid.

100 parts of nitrite which had been exposed to the sun, lost by heat from $19 \cdot 5$ to 20 of acid and water.

31. As the acil of the nitrite begins to be extricated from it at the temperature which is necessary to separate the water from it, I preferred analysing a nitrite whick could retain water, rather than trouble myself to analyse one which might have lost acid: I think therefore that the salt which was used in the following analysis retained a little water. It had been dried in the sand-bath with great care. It yielded

$$
\begin{array}{lll}
\text { Acid } \ldots \ldots \ldots \ldots \ldots & 1 \times \cdot 15 & 100 \\
\text { Oxide } \ldots \ldots \ldots \ldots & 81 \cdot 85 & 450
\end{array}
$$

